\title{
Perspectives on integrated water resource management and its relevance in understanding the water-energy-climate change nexus in South Africa
}

\author{
Steven Matome Mathetsa ${ }^{1,4^{*}}$, Mulala Danny Simatele ${ }^{1,2}$, Isaac T. Rampedi ${ }^{3}$, \\ Gerhard Gericke ${ }^{4}$ \\ 1 School of Geography, Archaeology and Environmental Studies, Department of Geography and Environmental \\ Studies, University of the Witwatersrand, Johannesburg, South Africa \\ 2 School of Science and Technology, Rusangu University, Monze Campus, Monze, Zambia \\ 3 Department of Geography, Environmental Management \& Energy Studies, University of Johannesburg, \\ Johannesburg, South Africa \\ 4 Risk and Sustainability Division, Research Testing and Development, Eskom Holdings SOC, 5 Lower \\ Germiston Road, Rosherville, Cleveland, South Africa.
}

ORCIDs: Mathetsa: https://orcid.org/0000-0001-5669-3991 Simatele: https://orcid.org/0000-0002-2161-1586

Rampedi: https://orcid.org/0000-0002-1868-8486 Gericke: https://orcid.org/0000-0001-7401-4091

\begin{abstract}
It is increasingly acknowledged that the water-energy-climate change (WECC) nexus is one of the synergies that pose a significant risk to achievement of sustainable development goals (SDGs), specifically numbers six, seven and thirteen. There are suggestions that climate change outcomes such as increased temperature and drought episodes have implications for water availability, which in turn affects energy production in countries dependent on hydropower, pump-storage or coal-generated electricity, including South Africa. This development therefore calls for improved understanding of how to effectively manage the challenges that arise from this nexus, to mitigate the impacts it may have on achieving the associated SDGs. This study, which is based on an in-depth appraisal of existing developments, assessed the potential of the integrated water resource management framework in understanding the WECC nexus and its implications for South Africa's sustainable development endeavours, particularly in the context of water resource management and utilisation. The study revealed South Africa's lack of integrated, effective, and efficient institutions and policy framework to comprehensively manage the challenges emanating from this nexus. It identified an urgent need to develop systems and processes through which South Africa can handle the challenges as well as capture the benefits that may be obtained from this nexus.
\end{abstract}

Keywords: climate change, energy security, water resource management, sustainable development

Journal of Energy in Southern Africa 30(3): 11-21

DOI: http://dx.doi.org/10.17159/2413-3051/2019/v30i3a5654

This work is licensed under a Creative Commons Attribution-ShareAlike 4.0 International Licence Published by the Energy Research Centre, University of Cape Town ISSN: 2413-3051 https://journals.assaf.org.za/jesa

Sponsored by the Department of Science and Technology

\footnotetext{
* Corresponding author: * Tel: +27 72720 4491;

email: steviemathetsa@gmail.com
} 


\section{Introduction}

The sustainable development concept is premised on the assertions revolving around the objective to meet the needs of the present generation without compromising those of the future (Omer, 2008; Masters, 2009; Mathetsa, 2016). This definition embeds within itself the importance of identifying strategies and systems aimed at supplying and conserving resources within the socio-economic developmental needs of communities (United Nations [UN], 1972; 1992; Kubiszewski and Cleveland, 2012). This focus is regarded as a way of establishing a balanced system on how to effectively achieve economic and social progress within the limits of environmental sustainability, as well as aligning national development to the targets embedded in the sustainable development goals (SDGs). Increased global and local demands for resources in both domestic and industrial use have, however, exerted immense pressure on natural resources to a point of untenable management. Chilundo et al. (2008) and Brazilian et al. (2011) have pointed out factors, such as a rapid increase in population growth, industrialisation and urbanisation, that are driving natural resources towards devastation. These remarks, therefore, instigate a re-examination of how resources are used and safeguarded in such a manner that SDGs are achieved.

As the supply of water and energy resources emerges as one of the central themes of modern human life, their global demand is expected to increase as the need to attain SDGs intensifies. The Global Water Partnership (2000) and Al Saidi (2017) have pointed out that water scarcity in most global communities requires that their security be treated as a main topical issue within sustainable development at large. It is, however, observed that obstacles such as rising climate vulnerabilities exacerbate water scarcity (Natural Resource Defence Council, 2010; Ziervogel et al., 2014; DeNicola et al., 2015; Nhamo et al., 2018), thus raising profound concerns as to how a sustainable supply of critical resources can be attained. This underlines the persistent necessity for society globally to strive for a balanced system across the management of natural resources.

Given the threat that shortages of resources are posing to SDGs, it is widely reported that food and energy production are amongst the essential socioeconomic sectors most vulnerable to these constraints (Carter and Gulati, 2014; Carpenter, 2015; Rasul and Sharma, 2016; Mabhaudhi et al., 2016). The extent of this vulnerability is likely to be experienced mainly in countries such as South Africa, where water availability and supply drives both electricity generation and food production, while energy is one of the most critical drivers of water treatment and distribution (Carpenter, 2015; International Energy Agency, 2016; Nhamo et al.,
2018). This points to the interconnection and interdependency between water and energy systems, which most developing countries are struggling with and striving to supply on a reliable and sustainable basis.

In many sub-Sahara African (SSA) countries, the interlinkage between water and energy remains significant in the region, particularly in countries such as South Africa where coal-combustion is still the main driver for electricity production. Energy generation through coal-combustion, however, is one of the biggest contributors to human-induced climate change through the release of greenhouse gases (Intergovernmental Panel on Climate Change, 2007; Omer, 2008) which is widely perceived to be threatening human existence and exerting enormous pressure on limited water resources (Mukheibir, 2008; Dennis and Dennis, 2012; Nkhonjera, 2017). These considerations further highlight the coupling between the systems of water, energy and climate change - the water-energy-climate change (WECC) nexus. Its occurrence in South Africa corroborates the findings of Head and Cammerman (2010) who argued that most global communities, particularly those at developing stages, are likely to be faced with the WECC nexus. These dynamics call for critical questions relating to the WECC management and its socio-economic and ecological interactions, in countries such as South Africa which have been identified as climate change hotspots (Ziervogel et al., 2014; DeNicola et al., 2015; Nhamo et al., 2018).

Despite the complex linkage of systems of water, energy and climate change, several studies have concurred that challenges such as the pragmatic lack of coordinated planning, policy integration, and a systematic approach impedes effective management of WECC and its components (Cammerman, 2009; Hussey and Pittock, 2012; Rasul and Sharma, 2016; Mabhaudhi et al., 2016; Stein et al., 2018; Nhamo et al., 2018). This challenge deepens doubts about the attainment of SDGs linked to these components. In developing countries such as South Africa, the risks associated with WECC are likely to be felt, as the lack of adequate and integrated management of water, energy, and climate change systems is intense (Scott et al., 2011). This necessitates the need to establish contemporary approaches that will broaden understanding of this nexus and effectively manage it in a way that positively contributes to sustainable development.

Within the WECC nexus, water is regarded as the central component (Walmsley et al., 2001; Prasad et al., 2012; Jagerskog et al., 2014). Its dominant role across various societal needs suggests that its sustainable management would benefit energy security while adapting to climate change. This observation supports the need for a shift in 
paradigms and adopting approaches which would facilitate sustainable systems of water resource management in order to minimise socio-economic and environmental risks associated with the WECC nexus. Studies within the sustainability sector have proposed different approaches for protecting and utilising water, including integrated water resource management (IWRM). The GWP (2000) and Leendertse et al. (2008), for example, found that this framework's ability to raise sufficient awareness, while promoting practical guidelines in a systematic and integrated approach, makes it one of the most useful tools available to promote sustainable water resource management. Considering the dire state of water resources in South Africa, there is a need to explore the potential and value of implementing the IWRM framework to address WECC conundrum.

The present study examined developments in the WECC nexus to explore its effective management through an integrative and holistic approach. Conducting a review on an emerging and complex subject such as WECC is a crucial contribution to providing dependable and general information regarding this nexus while identifying gaps that should be addressed. Bless et al. (2013) suggested that a review of this nature involves searching and studying of previous and current developments on the investigated problems without raising any controversy. The present study also explored the IWRM framework with the view to utilising it as a tool to widen the understanding and promotion of effective management of the WECC nexus in South Africa.

\section{Methodology}

This study examined the international developments, with an emphasis on SSA, especially South Africa, in water, energy and climate change systems, and thus the WECC nexus and IWRM framework. To this extent, a rapid appraisal of empirical academic and non-academic literature such as project and industry reports, books and presented papers was conducted. Additional developments were obtained from the Water Research Commission, a South African-based research institute that conducts and publishes studies within the water and environmental fields in the Southern Africa region. With a focus on themes such as sustainable water resource management, energy security, and climate change impacts, the criteria for inclusion in the appraisal were based on global, regional and local studies focusing mostly on different nexus types such as WECC, water-energy (WE) and water-energy-food (WEF). This methodology was influenced by suggestions of the limited work done on WECC in South Africa, which is intensified by a lack of broadened knowledge, and fragmented policy approach on the nexus. This appraisal was corroborated by extensive verbal interaction with a specialist within the field of WECC with the intention to gain further information on this nexus and its challenges within the SSA region.

\section{Results and discussion 3.1 Contextual developments on WECC nexus}

The SDGs numbers six, seven and thirteen underline the need for global communities to maximise the reliable supply of water and energy, while combating climate change and its related impacts (UN, 2015). Communities in SSA are faced with similar expectations. In South Africa for example, Winkler (2006) expressed the view that most of the country's socio-economic developmental needs could be achieved through an increased supply of energy. This, however, must be done within the parameters of safeguarding natural resources such as water, land and atmosphere. Although the need to address societal and ecological imperatives is intensifying, studies have mentioned the complex interlinkage between some of the key features of modern life as one of the synergies halting their attainment (Head and Cammerman, 2010; Bazilian et al., 2011; PahlWostl et al., 2018). Among those interlinkages, the complex connection between the systems of water, energy, food and, more recently, with the consideration of climate change, give rise to different forms of nexus. With uncertainties emerging from these nexus, concerns over the reliable supply of resources such as food, water, and energy, as well as their contribution towards climate change intensify. On the other hand, climate change impacts the availability of these resources in numerous forms.

Recent studies have made contrasting reports about when and how the nexus within the sustainable management discourse emerged (Siddiqi and Anadon, 2011; Conway et al., 2011; Muller, 2015; Pahl-Wostl et al., 2018; Simpson and Jewitt, 2019). While initial studies around the nexus are mostly limited to water and energy interactions and in some instance incorporate food production, Siddiqi and Anadon (2011) suggested that the need to acknowledge and understand the WE nexus was recognised as early as 1994. Muller (2015), however, asserted that recognition of such interlinkages arose as early as the 1970s. Irrespective of when it emerged, the socio-economic influence of the nexus encouraged its discussions at various global gatherings during the 2000s. For example, conferences such as the Gleneagles G8 Environmental Ministers' meeting in 2007, the Davos World Economic Forum in 2008, and Bali's United Nations Framework Convention on Climate Change meeting in 2008 resolved to strengthen the understanding and management of the water and energy interactions (European Cooperation in Science and Technology [COST], 2009; Cammer- 
man, 2009). Furthermore, the Bonn Nexus conference in 2011 reflected mainly on the interactions of water and energy together with food production, resulting in more studies embracing the triangular WEF nexus (Conway et al., 2011). These observations fortified the discussions and investigations around various types of nexus to gain momentum in both policy and research perspectives.

Until recently, most studies did not consider the impact of climate change on the nexus configurations. Climate vulnerability studies prompted global researchers to consider its role towards food, energy and water security. Studies in countries such as the United States (US), China, Spain and Australia were the first to focus mainly on the WE with brief considerations of climate change influence. For example, Hussey and Pittock (2012) found that the WE study conducted in the US in 2006 was one of the initial researches that embraced climate change role in the nexus. This and other subsequent developments resolved to fully incorporate climate change in coupled triangular interactions of water and energy.

Despite the emerging interest in the WECC nexus and its sustainable developmental impacts, studies on the in-depth understanding of this nexus and its consequences are still limited. This is confirmed by limited documented information on this nexus both at a global and regional level. Platonova and Leone (2012) and Yillia (2019) pointed out this as a concern for developing countries, particularly those in the SSA. Nkhonjera (2017) suggested that this region's lagging behind on climate change and its influential role on other sectors such as water and energy is attributed to uncertainties in climate and hydrological modelling, lack of financial resources and political will to develop and implement policy, particularly in developing regions. This raises resistance in recognition of paradigms such as WECC as well as policy development within them and is confirmed by recent studies in the SSA countries of Cameroon, Kenya and South Africa where WE and WEF nexus are still at the centre stage (Platonova and Leone, 2012; Ackom, 2014; Carter and Gulati, 2014; Mabhaudhi et al., 2016; Wakeford, 2017; Yillia, 2019).

The interlinkage between water, energy and climate change is a complex one, accentuated by interdependencies in multi-sectoral systems. For example, studies by Carpenter (2015) and Copeland and Carter (2017) maintained that, while a substantial part of the global energy production systems heavily depends on water availability for various processes such as raw material extraction and cooling, the treatment, supply and usage of water, particularly in domestic and industrial practices, is an energy-dependent process. This interdependency is intensified by the distance of water users from water resources, which exacerbates ener- gy needs in the water value chain. Conversely, the global overreliance of energy production on the fossil fuel combustion process results in the emission of greenhouse gases, which accelerates climate change. Despite climate change's influence on energy generation processes such as cooling, Ziervogel et al. (2014) and Kundzewics et al. (2016) concurred that its role in water availability is severe, as occurrences such as varying temperature, floods, precipitation and drought affect the hydrological cycle. These varying climatic conditions and other impacts such as water pollution exacerbate water shortages, thus putting pressure on energy production and its associated sectors. The severity of this water, energy and climate change interdependency is experienced on a global scale already. For example, studies by Siddiqi and Anadon (2011) and Carpenter (2015) pointed out that some countries in Europe, South America, and Asia had to reduce their electricity production because of water shortages intensified by climate variabilities, particularly drought and increased temperatures.

The SSA, a rapidly developing region characterised by prolonged water shortages because of its semi-arid geographical characteristics and increasing energy demands, is not resistant to WECC and its challenges. For example, while the region is striving to meet modern energy and water demands, Serdeczny et al. (2015) observed that this region is one of those where climate change outcomes will most be felt, in a number of sectors. Furthermore, Prasad et al. (2012) and Conway et al. (2015) indicated that drought and freshwater shortages in hydropower-dependent countries such as the Democratic Republic of Congo, Lesotho, Malawi, Kenya, Zimbabwe, and Zambia resulted in disruptions to the supply of energy. Despite these noticeable impacts of the WECC on the region's socioeconomic developmental needs, it is observed that WE and WEF are still at the centre stage of nexus researches. Ackom (2014), Stein et al. (2018) and Yillia (2019), however, suggested that the region should intensify how it considers climate change's role on WE and WEF, thus presenting the SSA with opportunities to look at prospects of managing WECC effectively.

South Africa is one of those SSA countries likely to be affected by risks emanating from WECC. For example, despite the country's well-documented water scarcity status, approximately $90 \%$ of the electricity is generated from water-reliant coal-combustion, nuclear, hydropower and pump-storage technologies (Eskom, 2016). Being one of the epicentres of the national developmental plans, power generation is supplied with $2 \%$ of the freshwater available in the country with reliable assurance, second only to the agricultural sector (Eskom, 2012; Department of Water and Sanitation [DWS], 2014). The country is, however, ranked among the top 


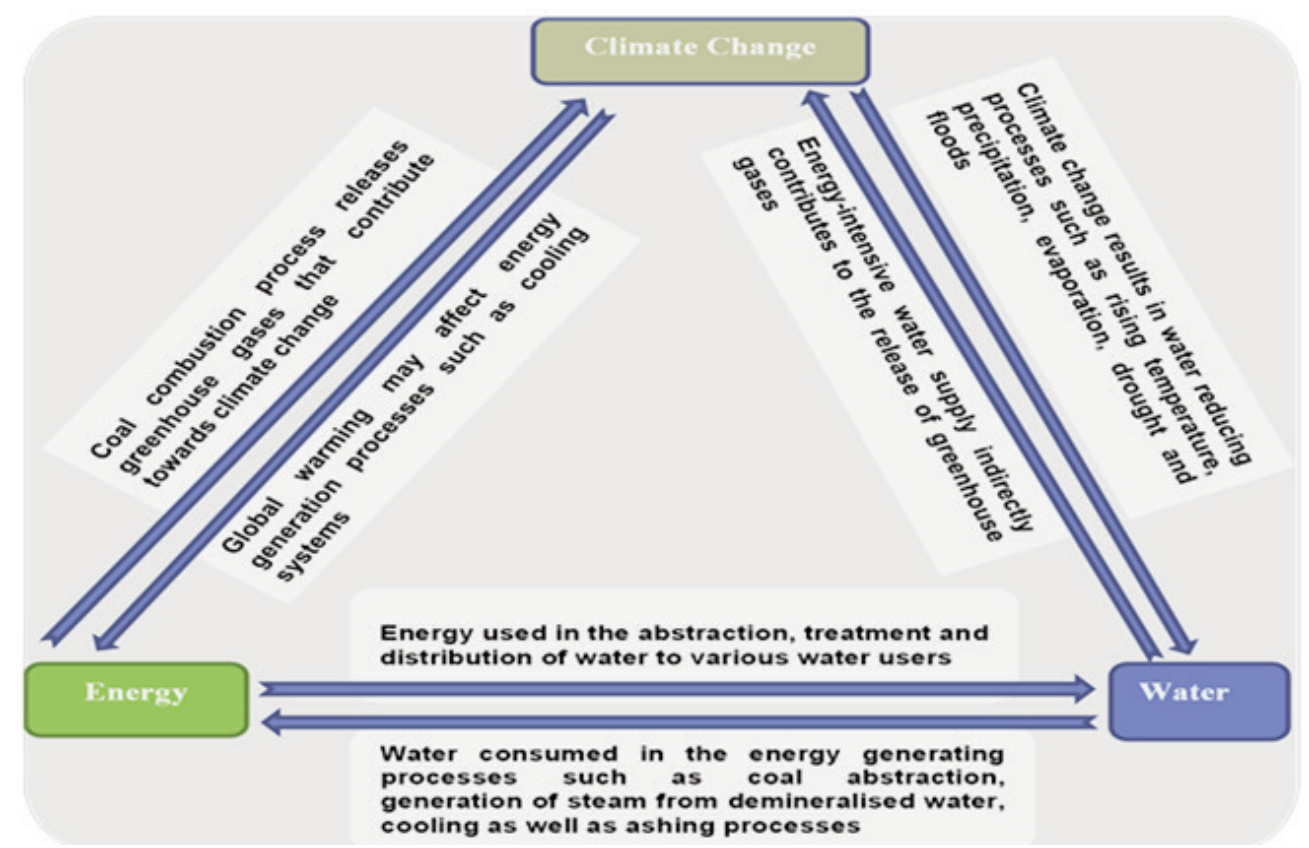

Figure 1: Coupled interactions between water, energy and climate change in South Africa.

producers of greenhouse gases, largely because of emissions from the power generation sector, specifically the coal-combustion technology (Carter and Gulati, 2014). The upsurge of climate change and influence from other anthropogenic activities such as urbanisation, exert pressure on already constrained water and energy resources. These observations show how the systems of water, energy and climate change are inextricably interconnected in the country, as elaborated in Figure 1. However, just like a situation at the global and regional context, the country has demonstrated a lack of knowledge and integration with regard to managing the WECC and its risks. However, recent studies such as those by Mabhaudhi et al. (2016) and Nhamo et al. (2018) concurred on the need to effectively manage the nexus in a holistic and integrated manner. The present study, therefore, suggests the need for the country to broaden its understanding of the WECC and to initiate discussions such as policy integration to combat the risks associated with this nexus.

\subsection{Governance on the WECC nexus}

Earlier investigations on WECC highlighted that partial understanding of this nexus results in a 'silo' approach, especially from the governance perspective (Cammerman, 2009; Head and Cammerman, 2010). Lack of a coordinated planning system, practices and policy development between the sectors of water, energy and climate change is a concern in many countries. Investigations are, however, gaining momentum elsewhere to minimise these governance setbacks (Goldstein et al., 2008; Energy and Water Integrated Act [EWIA], 2009). For example, the US study on WE recommended the development of an integrated policy on water and energy (Goldstein et al., 2008). In response, the EWIA policy was developed with the view to direct the US towards improving governance of the nexus through an in-depth analysis of the impact of energy development and production on the country's water resources (EWIA, 2009). Despite not being signed into law, this strategy encouraged other parts of the US and other countries to broaden investigations of various nexus studies in an integrated manner. For example, subsequent investigations and publications of reports such as the 'Waterenergy nexus: Challenges and opportunities' (United State Department of Energy [US DoE], 2014) show efforts to promote a systematic, integrated and proactive way to address the nexus to ensure a reliable supply of energy under different water and climate constraints.

Despite such efforts and progress on incorporating all nexus components in planning, some countries still lag behind. South Africa is one of those that still approach governance of water, energy and climate change policy and implementation in isolation. Studies by Mabhaudhi et al. (2016) and Nhamo et al. (2018) showed that sectoral approaches driven by sector mandates which seldom refer to each other, are cause for concern about effective governance of these systems. This is despite the country's adoption of the National Environmental Management Act, Number 107 of 1998, which endorses the integrated environmental management approach as one of its objectives. This policy segmentation demonstrates a fragmented approach and lack of collective effort from the key stakeholders in the management of energy, water and climate change. For example, with policies such as the National Water Resource Strategy (NWRS) in place, the DWS is mandated to ensure that man- 
agement and protection of water resources in South Africa are fulfilled (DWS, 2014). Water policies mostly acknowledge the impact of climate change on water resources, but without providing a plan as to how these will be dealt with. Policies relating to water resources' adaptative and resilient strategies on climate change are developed by the Department of Environmental Affairs (Department of Environmental Affairs [DEA], 2015). This is a concern, as there would be overlap in terms of implementation. Furthermore, despite assurances on freshwater supply for the energy sector, water resource constraints highlight the need for integrated planning to secure water supply for power generation. However, recent delays in aligning water supply to energy generation raise gaps in terms of policy planning and implementation between these sectors. Similar misalignments are observed in energy planning. For example, despite proposing a mix that will decarbonise power generation sector with reduced water consumption, the 2010-2030 Integrated Resource Plan (IRP) highlights that $65 \%$ of the country's energy will still be generated using the water-reliant coal combustion process (DoE, 2010). This policy is silent on how the power generation sector will be reliably supplied with water and provides little suggestions on the improvement of water management at the operational level.

Furthermore, the IRP offers no strategy as to how the energy sector will reduce their greenhouse gas emissions from coal-fired power stations, except through decommissioning of power plants. Additionally, Madhlopa et al. (2016) noted that the IRP hardly addresses the water impacts resulting from the lifecycle of energy production, mainly raw material extraction such as coal mining, which is seen as the responsibility of the Department of Mineral Resources. The National Climate Change Response Policy was drafted to manage challenges emanating from climate change (DEA, 2015). The policy further recommended that the adaptation strategies be implemented within the NWRS, while climate mitigation strategies in the energy sector include the reduction of carbon emissions (DEA, 2015). Trollip and Bouller (2017), however, contended that this policy can be attributed to lack of coordination and alignment between the different role players in DEA, DWS and DoE.

These observations point to a critical gap emerging from the governance of WECC components, where governmental structures still operate in a segregated manner in South Africa. This gap owes much to the unaligned institutional and policy framework within which a coordinated and integrated approach towards management of water and energy resources in the context of climate change can be pursued. Several studies suggest delineating this complex issue to effectively address it. For example, in addressing myriad water issues, developing a consensus that proposes a shift towards 'nexus thinking' when addressing issues related to the WECC is an imperative one (Global Donor Platform for Rural Development, 2017; Taylor-Wood and Fuller, 2017). Reynolds and Cranston (2014) further suggested that nexus thinking can respond to the risks associated with different configurations. Nexus thinking is intended to promote viewing a specific problem from different angles to create an understanding of the bigger picture holistically and systematically while addressing other associated systems. Therefore, considering its centrality in WECC, an approach where water-related challenges are addressed while equally considering issues arising from energy and climate change could be an effective solution for this nexus. In Australia, studies by Cammerman (2009) and Head and Cammerman (2010) suggested that this integrated approach could be achieved through the implementation of the IWRM framework, which emerges from the water management perspective.

\subsection{Towards the integrated approach}

While the developments on nexus are still at an infant stage, research conducted on sustainable water resource management resulted in the paradigms such as the IWRM, which focusses on addressing complex systems involving water (GWP, 2000; Pollard and Du Toit, 2008; Heldt et al., 2017). This research stimulated suggestions that effective management of water should be at the apex of WECC as it may influence how to minimise the nexus risks to socio-economic development (Prasad et al., 2012; Jagerskog et al., 2014). Cammerman (2009), for example, asserted that lack of broadened understanding of the complexities and interactions around WECC may result in unsustainable management and utilisation of water, which crosscuts most sectors, including food production. The question raised in this study is, however, how the efficient management of water resources presents an amplified system that builds their resilience towards climate change, thus easing energy security and the associated sustainable development threats.

While different approaches towards managing water may be applicable, Cammerman (2009) and Bindra et al. (2013) contended that the IWRM approach is one of the useful tools that can endorse, structure and mutually enforce management of this resource holistically and sustainably. Despite this framework being around for some time, Biswas (2008) and Nesheim et al. (2010) maintained that it only started being amplified by scientists and the GWP around the 1990s, and was strengthened only around the early 2000s. Initial discussions at various gatherings such the Dublin's UN-Water and Environment Conference in 1992, Rio's World Summit in 1992, Bonn's International 
Conference on Freshwater in 2001, and the Johannesburg World Summit on Sustainable Development in 2002, intensified the need to implement this framework for improved water resources management. Furthermore, the usefulness of this framework was recognised by at least $65 \%$ of countries which adopted it prior to the Rio Plus Conference in 2012 ( Al-Saidi, 2017).

According to GWP (2000), this framework can shed light on how to develop regulations and regional plans for water governance in an integrated manner. This will ensure effective environmental management while defining institutional roles and stakeholder participation within the management of water resources. Studies within water resource management, however, show that this framework continues to receive criticism from some practitioners and scientists (Biswas, 2004; Fulazzaky, 2014; Held et al., 2017). For instance, Biswas (2004, 2008), found that the IWRM has demonstrated a lack of technical and institutional ability to address water resource challenges, thus resulting in setbacks regarding how it is implemented. This observation raises concern within the water fraternity as to whether it is a practical tool to provide solutions for current and future challenges. Biswas (2008) further emphasised that this IWRM is not effective enough when applied across varying sectors such as agriculture and energy or even at a macro scale. Other studies, however, presented a different observation, arguing that IWRM can promote integrated management across different sectors such as energy, food production and water (Leendertse et al., 2008; Nesheim et al., 2010). Bringing together different water users with a common goal promotes integration as all views have the potential to be considered in planning and policy development. Doubts about the effectiveness of IWRM resulted in other nations opting against its adoption. For example, some European countries opted to implement the European Union Water Framework Directive, a policy developed to provide alternative solutions to their water challenges (Heldt et al., 2017).

In many developing nations, such as those in SSA, lack of participation and political will still weaken IWRM's implementation. Muller (2015) raised factors such as the focus on growing the economy as well as climate vulnerability as some of the challenges impeding IWRM implementation in these nations. This underlines the need for a more robust and effective approach if water resource management improvements are to be attained. In South Africa, notably, challenges arising from coordination and policy implementation threaten the country's already stressed water resources to a point where its availability to sectors such as energy and food production cannot be guaranteed. Funke et al. (2007), however, maintained that, through a holistic and systematic manner presented in IWRM, this framework is a necessity if the country is to address its short-term risks and achieve long-term security of water resources, particularly those associated with scarcity and inequitable distribution, as well as mismatches identified in agriculture, industry and energy sector located on heavily concentrated water demand regions such as the highveld in Mpumalanga. Funke et al. (2007) and Karar (2008), however, indicated that the country's application of IWRM is still limited to a water perspective or policy development within this sector.

Given that WECC components are governed in segregation despite the interlinkages, can this be mitigated by the IWRM's ability to influence governance through the promotion of a multi-participatory approach as well as consideration of different driving forces and their linkages? Cammerman (2009) suggested that this framework's proactive risk-based approach is one of its strengths, one that can promote an integrated approach on policies and strategies, while addressing associated challenges, particularly towards the socio-economic development agenda. This is despite it arising from the water resource management perspective.

\section{Conclusions}

This study examined developments in one of the emerging paradigms that threaten the achievement of sustainable development goals: water-energy-climate change (WECC) nexus. The study revealed two key findings. Firstly, it is evident that studies of the WECC nexus are still limited internationally. Most nexus studies have, to date, focused mainly on water-energy and water-energy-food configurations. A similar observation is made in South Africa where there is an inextricable linkage between systems of water, energy and climate change. Secondly, despite gaps being identified in the management of different nexus configurations, South Africa still lack policy integration. Currently, various government departments such as the Department of Water and Sanitation, Department of Environmental Affairs and Department of Energy generally address sectoral requirements instead of adopting an integrated approach. The study contributes towards closing the existing knowledge gap on WECC, thus assisting South Africa to understand and address myopia about the relationship between water, energy, and climate change, and promote discussions on an integrated approach in the development of institutional and policy framework.

\section{Acknowledgments}

Thanks to Eskom's Research, Testing and Development division for funding the study. The views presented in this paper are those of the authors and do not necessarily reflect the views of Eskom 


\section{Author roles}

S. Mathetsa: Main author and researcher. Data collection and write-up.

M. Simatele: $\mathrm{PhD}$ supervisor, reviewer.

I. Rampedi: $\mathrm{PhD}$ co- supervisor, reviewer.

G. Gericke: Industrial mentor, reviewer.

\section{References}

Ackom, E. 2014. Energy, water and climate nexus: A case study of Cameroon. In Nexus 2014: Water, food, and energy. Online: http://orbit.dtu.dk/files/128129576/nexus_2014_abstract_book.pdf (Accessed: 14 March 2018). https://doi.org/10.1115/imece2014-36502

Al-Saidi, M. 2017. Conflicts and security in integrated water resource management. Environmental Science and Policy 73: 38-44. https://doi.org/10.1016/j.envsci.2017.03.015

Bindra, S. P., Hamid, A., Salem, H., Hamuda, K. and Abulifa, S. 2013. Sustainable integrated water resources management for energy production and food security in Libya. Procedia Technology 12: 747-752. https://doi.org/10.1016/j.protcy.2013.12.558

Biswas, A. K. 2004. Integrated water resources management: A reassessment. International Water Resources Association 29(2): 248-256. https://doi.org/10.1080/02508060408691775

Biswas, A. K. 2008. Integrated Water Resources Management: Is it working? International Journal of Water Resource Development 24(1): 5-22.

Bless, C., Higson-Smith, C. and Sithole, S. 1. 2013. Fundamentals of social research methods: an African perspective. $5^{\text {th }}$ edition. Juta \& Co. South Africa.

Brazilian, M., Rogner, H., Howells, M., Hermann, S., Douglas, A., Gielen, D., Steduto, P., Mueller, A., Komor, P., Tol, S. J. R. and Yumkella, K. K. 2011. Considering the energy, water and food nexus: Towards an integrated modelling approach. Energy Policy 39: 7896-7906. https://doi.org/10.1016/j.enpol.2011.09.039

Cammerman, N. 2009. Integrated water resource management and the water, energy, climate change nexus: a discussion report. Masters Thesis, University of Queensland, Australia.

Carpenter, A. M. 2015. Water availability and policies for the coal power sector. IEA Clean Coal Centre. Report No. ccc/256. United Kingdom.

Carter, S. and Gulati, M. 2014. Climate change, the food energy water nexus and food security in South Africa: Understanding the food energy water nexus. WWF-SA: 1-17. https://doi.org/10.1115/imece2014-36502

Chilundo, M., Kelderman, P. and O'Keeffe, J. H. 2008. Design of a water quality monitoring network for the Limpopo River Basin in Mozambique. Physics and Chemistry of the Earth 33: 655-665. https://doi.org/10.1016/j.pce.2008.06.055

Conway, D., Van Garderen, E. A., Deryng, D., Dorling, S., Krueger, T., Landman, W., Lankford, B., Lebek, K., Osborn, T., Ringler, C., Thurlow, J., Zhu, T. and Dalin, C. 2015. Climate and Southern Africa's water-energyfood nexus. Nature Climate Change 5(9): 837-846. https://doi.org/10.1038/nclimate2735

Copeland, C. and Carter, N. T. 2017. Energy-water nexus: The water sector's energy use. Congressional Research Service Report prepared for members and committees of congress, 24 January 2017.

European Corporation for Science and Technology (COST). 2009. The energy-water nexus: Managing the links between energy and water for a sustainable future. COST explanatory workshop, Brussels, 19-21 January 2009.

DeNicola, E., Aburizaiza, S. O., Siddique, A., Khwaja, H., and Carpenter, D. O. 2015. Climate Change and Water Scarcity: The Case of Saudi Arabia. Annals of Global Health 81(3): 342-353. https://doi.org/10.1016/j.aogh.2015.08.005

Dennis, I. and Dennis, R. 2012. Climate change vulnerability index for South African aquifers. Water SA 38(3): 417 426. https://doi.org/10.4314/wsa.v38i3.7

Department of Energy (DoE). 2013. Integrated Resource Plan for electricity: 2010-2030 Revision 2. DoE, Pretoria, South Africa. Online:http://www.energy.gov.za/IRP/irp\%20files/IRP2010_2030_Final_Report_20110325.pdf (Accessed: 20 February 2018).

Department of Environmental Affairs. 2015. National climate change response policy, White Paper. Pretoria, South Africa.

Department of Water and Sanitation. 2014. National water resource strategy: Water for equitable and sustainable future. Government Printers, Pretoria, South Africa.

Electricity Power Research Institute. 2010. Sustainable water resource management: Case study on new water paradigms, 3. Online: 
http://www.ndwrcdp.org/documents/DEC6SG06a/Case\%20Studies\%20on\%20New\%20Water\%20Paradigm.pdf (Accessed: 20 April 2018).

Energy and Water Integration Act. 2009. S 539 of The Bill: The senate of the United States, $111^{\text {th }}$ congress $1^{\text {st }}$ session. The United States, 5 March 2009.

Eskom. 2012. Water, energy and development: Sustainability group, research, testing and development. Johannesburg, South Africa.

Eskom. 2016. Eskom water management policy. Document identifier: 32-1163. Online:https://hyperwave.eskom.co.za/Eskom/Group\%20Capital/Eskom\%20Real\%20Estate/SHEQ/Environmental \%20Management\%20System_ISO\%2014001/North\%20West\%20\%26\%20Free\%20State/Free\%20State/Bloemfon tein/4.4.6.\%20Operational\%20̄Controls/Water\%20Management/Policy.pdf (Accessed: 18 June 2018).

Fulazzaky, A. M. 2014. Challenges of integrated water resources management in Indonesia. Water 6: 2000-2020. https://doi.org/10.3390/w6072000

Funke, N., Oelofse, S. S. H., Hattings, H., Ashton, P. J. and Turton, A. R. 2007. IWRM in developing countries: Lessons from the Mhlatuze catchment in South Africa. Physics and Chemistry of the Earth 32: 1237-1245. https://doi.org/10.1016/j.pce.2007.07.018

Goldstein, N. C., Newmark, R. L., Whitehead, D. C., Burton, E., McMahon, J. E., Ghatikar, G. and May, D. W. 2008. The energy-water nexus and information exchange: Challenges and opportunities. International Journal of Water 4(1\2): 5-24. https://doi.org/10.1504/ijw.2008.018144

Global Donor Platform for Rural Development. 2017. Online: https://www.donorplatform.org/news-agenda2030/exploring-the-power-of-nexus-thinking-in-sdgs-implementation.html (Accessed: 01 March 2019).

Global Water Partnership. 2000. Integrated water resources management: Report by Technical Advisory Committee. TAC background papers no. 4, Stockholm, Sweden. Online: https://www.gwp.org/globalassets/global/toolbox/publications/background-papers/04-integrated-water-resources-management-2000-english.pdf (Accessed: 26 June 2017).

Head, B. and Cammerman, N. 2010. The water-energy nexus, a challenge for knowledge and policy. Urban Water Security Research Alliance, Technical report No. 39. Online: http://www.urbanwateralliance.org.au/publications/UWSRA-tr39.pdf (Accessed: 28 March 2018).

Heldt, S., Rodriquez-de-Francisco, J. C., Dombrowsky, I., Feld, C. K. and Karthe, D. 2017. Is the EU WFD suitable to support IWRM planning in non-European countries?: Lessons learnt from the introduction of IWRM and river basin management in Mongolia. Environmental Science and Policy 75: 28-37. https://doi.org/10.1016/j.envsci.2017.05.009

Hussey, K. and Pittock, J. 2012. The energy-water nexus: Managing the links between energy and water for sustainable future. Ecology and Society 17(1): 31-39. https://doi.org/10.5751/es-04641-170131

Intergovernmental Panel on Climate Change (IPCC). 2007. Climate change 2007: Impacts, adaptation and vulnerability. Contribution of working group II to the fourth assessment report of the IPCC by M.L. Parry, O.F. Canziani, J.P. Palutikof, P.J. van der Linden and C.E. Hanson, Eds., Cambridge University Press, Cambridge, UK, 976. https://doi.org/10.2134/jeq2008.0015br

International Energy Agency (IEA). 2016. Energy, climate change and environment: A report by IEA. Online: http://www.iea.org/publications/freepublications/publication/ECCE2016.pdf (Accessed: 23 May 2017). https://doi.org/10.1787/9789264239272-en

Jagerskog, A., Clausen, T. J., Holmgren, T. and Lexen, K. 2014. Energy and Water: The vital link for a sustainable future: Report for the world water week. Report no 33. Stockholm, Sweden, $31^{\text {st }}$ August $-5^{\text {th }}$ September 2014.

Karar, E. 2008. Integrated water resource management (IWRM): Lessons from implementation in developing countries: Foreword to the IWRM conference special edition. Water SA 34(6): 661-664. https://doi.org/10.4314/wsa.v34i6.183666

Kubiszewski, I. and Cleveland, C. 2012. United Nations Conference on Environment and Development, Rio de Janeiro, Brazil. Online: http://editors.eol.org/eoearth/wiki/United_Nations_Conference_on_Environment_and_Development_(UNCED),_Ri o_de_Janeiro,_Brazil (Accessed: 26 March 2018). https://doi.org/10.1007/springerreference_29770

Leendertse, K., Mitchell, S. A. M. and Harlin, J. 2008. IWRM and the environment: A view on their interaction and examples where IWRM led to better environmental management in developing countries. Water SA 34(6): 691698. https://doi.org/10.4314/wsa.v34i6.183671

Mabhaudhi, T., Mpandeli, S., Madhlopa, A., Modi, A. T., Backeberg, G. and Nhamo, L. 2016. Southern Africa's water-energy nexus: Towards regional integration and development. Water 8(6): 1-21. https://doi.org/10.3390/w8060235

Madhlopa, A., Pegram, G., Sauka, S., Sparks, D., Keen, S. and Moorlach, M. 2016. The water-energy nexus in the context of climate change: Investigating trade-offs between water use efficiency and renewable energy options for South Africa. Report to the Water Research Commission. WRC Report No 2239/1/15. March 2016. https://doi.org/10.1016/j.rser.2015.03.051 
Masters, L. 2009. Climate change, energy and South Africa's foreign policy: The road to Copenhagen. South African Institute of International Affairs, Occasional Paper No. 47.

Mathetsa, S. 2016. Assessing water quality status by means of the Driver-Pressure-State-Impact-Response (DPSIR) model around Mapungubwe National Park, Limpopo Province, South Africa. MSc Thesis. University of South Africa, South Africa.

Mukheibir, P. 2008. Water resources management strategies for adaptation to climate-induced impacts in South Africa. Water Resources Management 22: 1259-1276. https://doi.org/10.1007/s11269-007-9224-6

Muller, M. 2015. The 'nexus' as a step back towards a more coherent water resource management paradigm. Water Alternatives 8(1): 675-694.

Natural Resource Defense Council (NRDC). 2010. Climate change and water resource management, adaptation strategies for protecting people and the environment. Available online: https://www.nrdc.org/sites/default/files/waterandclimate.pdf (Accessed: 05 May 2017).

Nesheim, I., McNeill, D., Joy, K. S., Manasi, S., Nhung, D. T. K., Portela, M. M. and Paranjape, S. 2010. The challenges and status of IWRM in four river basins in Europe and Asia. Irrigation and Drainage Systems 24(3-4): 205221. https://doi.org/10.1007/s10795-010-9103-9

Nhamo, L., Ndlela, B., Nhemachena, C., Mabhaudhi, T., Mpandeli, S. and Matchaya, G. 2018. The water-energyfood nexus: Climate risks and opportunities in Southern Africa. Water 10 (5): 567-584. https://doi.org/10.3390/w10050567

Nkhonjera, K. G. 2017. Understanding the impact of climate change on the dwindling water resources of South Africa, focusing mainly on Olifants River basin: A review. Environmental Science and Policy 71: 19-29. https://doi.org/10.1016/j.envsci.2017.02.004

Omer, M. A. 2008. Energy, environment and sustainable development. Renewable and Sustainable Energy Reviews 12: 2265-2300. https://doi.org/10.1016/j.rser.2007.05.001

Pahl-wostl, C., Bhaduri, A., and Bruns, A. 2018. The nexus of water, energy and food-an environmental governance perspective. Environmental Science and Policy. https://doi.org/10.1016/j.envsci.2018.06.021

Platonova, I. and Leone, L. 2012. The energy-water nexus in the context of climate change in developing countries: Experiences from Latin America, East and Southern Africa. Synthesis Report for Climate Change and Water Program, Ottawa, Canada, 7 November 2012.

Pollard, S. and Du Toit, D. 2008. Integrated water resource management in complex systems: How the catchment management strategies seek to achieve sustainability and equity in water resources in South Africa. Water SA 34(6): 671-680. https://doi.org/10.4314/wsa.v34i6.183668

Prasad, G., Boulle, M., Boyd, A., Rahlao, S., Wlokas, H. and Yaholnitsky, I. 2012. Energy, water and climate change in Southern Africa: What are the issues that need further investment and research? Energy Research Centre, University of Cape Town, Cape Town, South Africa. https://doi.org/10.17159/sajs.2016/20160202

Rasul, G. and Sharma, B. 2016. The nexus approach to water-energy-food security: An option for adaptation to climate change. Climate Policy 16(6): 682-702. https://doi.org/10.1080/14693062.2015.1029865

Reynolds, J. and Cranston, G. 2014. Nexus thinking: Can it slow the great acceleration?. Economic and Social Research Council. Available online: https:/www.cisl.cam.ac.uk/resources/latest-publications/nexus-thinking-can-itslow-the-great-acceleration. (Accessed: 11 March 2019)

Scott, A. C., Pierce, A. S., Pasqualetti, M. J., Jones, L. A., Montz, B. E. and Hoover, H. J. 2011. Policy and institutional dimensions of the water-energy nexus. Energy Policy 39: 6622-6630. https://doi.org/10.1016/j.enpol.2011.08.013

Siddiqi, A. and Anadon, D. L. 2011. The water-energy nexus in Middle East and North Africa. Energy Policy 39: 4529-4540. https://doi.org/10.1016/j.enpol.2011.04.023

Simpson, G. B. and Jewitt, G. P. W. 2019. The development of the water-energy-food nexus as a framework for achieving resource security: A review. Frontiers of Environmental Science. 7:8. https://doi.org/10.3389/fenvs.2019.00008

Sparks, D., Madhlopa, A., Keen, S., Moorlach, M., Dane, A., Krog, P. and Dlamini, T. 2014. Renewable energy choices and their water requirements in South Africa. Journal of Energy in Southern Africa 25(4): 80-92. https://doi.org/10.17159/2413-3051/2014/v25i4a2241

Stein, C., Pahl-wostl, C. and Barron, J. 2018. Towards a relational understanding of the water-energy-food nexus: analysis of embeddedness and governance in the Upper Blue Nile region of Ethiopia. Environmental Science and Policy. https://doi.org/10.1016/j.envsci.2018.01.018.

Taylor-Wood, E. and Fuller, D. 2017. 'Nexus thinking' for a secure and sustainable future. Available online: http://www.entura.com.au/nexus-thinking-secure-sustainable-future (Accessed: 01 March 2019).

Trollip, H. and Boulle, M. 2017. Challenges associated with implementing climate change mitigation policy in South Africa. Energy Research Centre, University of Cape Town, Cape Town, South Africa. https://doi.org/10.15641/ghi.v2i1.728

United Nations. 1972. Report of the United Nations conference on the human environment. Stockholm, 5-16 June 
1972, Document No. A/CONF.48/14/Rev.1. United Nations Publications, New York, USA. https://doi.org/10.18356/7f7f8caf-en

United Nations. 1992. United Nations framework convention on climate change. online:http://unfccc.int/files/essential_background/background_publications_htmlpdf/application/pdf/conveng.pdf Report No. FCCC/INFORMAL/84 (Accessed: 15 March 2017).

United Nations. 2015. Sustainable Development Goals Post-2015: Transforming our world-the 2030 agenda for sustainable development. In: Resolution adopted by the General Assembly on 25 September 2015. Available online. https://sustainabledevelopment.un.org/focussdgs.html (Accessed: 28 March 2018).

United States Department of Energy (US DoE). 2014. The water-energy nexus: Challenges and opportunities. Report for the US DoE, June 2014.

Wakeford, J. J. 2017. The water-energy-food nexus in a climate-vulnerable, frontier economy: The case of Kenya. Report Prepared for the United Kingdom department for international development by the Sustainability Institute South Africa, March 2017.

Walmsley, J., Carden, M., Revenga, C., Sagona, F. and Smith, M. 2001. Indicators of sustainable development for catchment management in South Africa - Review of indicators from around the world. Water SA 27: 539-550. https://doi.org/10.4314/wsa.v27i4.4968

Winkler, H., Davidson, O., Kenny, A., Prasad, G., Sparks, D., Howells, M. and Alfstad, T. 2006. Energy policies for sustainable development in South Africa, options for the future. Energy Research Centre, University of Cape Town, Cape Town. https://doi.org/10.15641/ghi.v2i1.728

World Bank. 2017. Modeling the water-energy nexus: How do water constraints affect energy planning in South Africa?. World Bank, Washington DC. https://doi.org/10.1596/26255

Yillia, P. 2019. Personal communication, 15th May 2019. Dr. Paul Yillia, International Institute for Applied Systems Analysis, Laxenburg, Lower Austria, Austria.

Ziervogel, G., New, M., Van Gardener, E. A., Midgley, G., Taylor, A., Hamann, R., Stuart-Hill, S., Myers, J. and Warburton, M. 2014. Climate change impacts and adaptation in South Africa. WIREs Climate Change 5: 605620. https://doi.org/10.1002/wcc.295. 